\title{
NEED ASSESSMENT AND EFFECT OF SEX EDUCATION ON AWARENESS AND KNOWLEDGE AMONG PRIMARY SCHOOL STUDENTS IN KLATEN, CENTRAL JAVA
}

\author{
Franciscus Xaverius Wartoyo \\ School of Education (STKIP) PGRI Sidoarjo, Klaten
}

\begin{abstract}
BACKGROUND: Lack of knowledge in reproductive health and weak parental control may have undesired impact on children. There appeared the need of sex education and teaching in reproductive health for school children. This study aimed to investigate the need and effect of sex education on awareness and knowledge in reproductive health among primary school students.
\end{abstract}

SUBJECT AND METHODS: This was a qualitative study conducted in Klaten, Central Java. Some students from Kanisius Primary School, Jombor, Klaten, were selected as study subjects. The intervention in this study was sex education and reproductive health class, integrated with science, physical education, and religion classes. The data were collected by in-depth interview and observation.

RESULTS: School children under study expressed the need for sex education and reproductive health, in order to inform and to raise awareness on these topics among them. In Kanisius Primary School under study, sex education and teaching in reproductive health were integrated with science, physical education, and religion classes. Qualitative evaluation showed that sex education and teaching in reproductive health had been able to increase awareness in sexual problem, increase knowledge in reproductive organs, reproductive health, and sexually-transmitted diseases. They were more knowledgeable on how to anticipate sexual harassment and to prevent sexually-transmitted diseases. They were also aware of the need to avoid pornography.

CONCLUSION: There is a need of integrated sex education and teaching in reproductive health among school children. This sex education and teaching in reproductive health can improve knowledge in reproductive health, increase awareness of sexual issues, and anticipate sexual harassment among primary school students.

Keywords: sex education, reproductive health, sexual harassment, school children 